\begin{tabular}{|ll|l|}
\hline Submitted $:$ 2021-02-24 & Accepted $:$ 2021-07-03 \\
\hline Revised $:$ 2021-04-18 & Published $: 2021-07-19$ \\
\hline
\end{tabular}

\title{
Camtasia Studio: Software multimedia dalam Pembelajaran Menyimak Arab di Era Industri 4.0
}

\author{
Nur Toifah \\ UIN Maulana Malik Ibrahim Malang \\ nur.toifah@uin-malang.ac.id
}

\begin{abstract}
A teacher is the spearhead of education, he must be able to revolutionize the teaching process properly, namely by changing the curriculum, strategies, materials, evaluation, and learning media that are in accordance with the demands of the 4.0 industrial revolution. This is the responsibility of all teachers, including Arabic teachers in Arabic listening skills in ST class. 12, Special Program for Arabic Language Development at State Islamic University of Maulana Malik Ibrahim Malang which uses Camtasia studio software in Arabic listening learning. The method of this research is descriptive qualitative. This media is useful for students in the form of increasing their learning motivation, changing behavior, providing new motivation and refreshment, providing meaningful lessons, expanding experiences and insights, and achieving the learning objectives of Arabic listening, as well as preparing them to face the era of the industrial revolution 4.0. The result of this research is that learning Arabic listening with Camtasia studio software media has three stages, namely the preliminary stage, which includes orientation, apperception, motivation, giving references, second: the core stage of learning, which includes observing, exploring, associating, communicating, and third: the closing stage, which includes conclusions, reflection and evaluation, motivation, and also prayers and greatings.
\end{abstract}

Keywords: Arabic listening, multimedia software, camtasia studio 


\begin{abstract}
Abstrak
Seorang pengajar adalah ujung tombak pendidikan, ia harus mampu merevolusi proses pengajarannya dengan baik, yaitu dengan mengubah kurikulum, strategi, materi, evaluasi, juga media pembelajaran yang sesuai dengan tuntutan revolusi industry 4.0. Hal itu menjadi tanggung jawab semua pengajar, termasuk pengajar bahasa Arab dalam keterampilan menyimak Arab di kelas ST. 12 Program Khusus Pengembangan Bahasa Arab UIN Maulana Malik Ibrahim Malang yang menggunakan media software Camtasia studio dalam pembelajaran menyimak Arab. Metode dari penelitian ini adalah deskriptif kualitatif. Media ini bermanfaat bagi peserta didik dalam meningkatkan motivasi belajar mereka, merubah tingkah laku, memberikan motivasi baru dan penyegaran, memberikan pelajaran yang bermakna, memperluas pengalaman dan wawasan, serta tercapainya tujuan pembelajaran menyimak Arab, juga mempersiapkan mereka dalam menghadapi era revolusi industry 4.0. Hasil dari peneletian ini adalah pembelajaran menyimak Arab dengan media software Camtasia studio memiliki tiga tahapan, yaitu tahap pendahuluan, yang mencakup orientasi, apersepsi, motivasi, pemberian acuan, ke-dua: tahap inti pembelajaran, yang mencakup mengamati, mengeksplorasi, mengasosiasi, mengkomunikasi, dan ke-tiga: tahap penutup, yang mencakup pengambilan kesimpulan, refleksi dan evaluasi, motivasi, serta penutup do'a juga salam.
\end{abstract}

Kata Kunci: menyimak Arab, software multimedia, camtasia studio

\title{
A. Pendahuluan
}

Revolusi industri 4.0 berkembang pesat pada era saat ini. Segala permasalahan kehidupan manusia dipermudah dengan hadirnya teknologi. Siapapun juga tidak dapat menolak hadirnya era globalisasi ini, yang mana kemajuan teknologi digital dapat melampaui seluruh batas teritorial dan semua aspek kehidupan manusia, seperti aspek pendidikan, ekonomi, politik, budaya, dan juga seni. (Rukiyah, 2020)

Pada saat ini, daya komputasi dan data dipergunakan dengan tidak terbatas, karena adanya perkembangan teknologi informasi digital yang berperan sangat penting dalam pergerakan dan konektifitas manusia dengan mesin. Dengan demikian, teknologi informasi menjadi salurang pertama 
dan utama dalam kehidupan manusia demi terbangunnya eksistensi di semua aspek ruang, termasuk aspek pendidikan.

Tantangan bagi tenaga pendidik saat ini adalah menjadikan pembelajaran aktif, kreatif, inovatif, menarik, dan menyenangkan bagi peserta didik. Untuk itu, guna mengimbangi arus revolusi ini, inovasi dan strategi pembelajaran berbasis teknologi sangat diperlukan, dan tentunya sesuai dengan tantangan perkembangan zaman ini. Hal ini berlaku bagi semua mata pelajaran, termasuk mata pelajaran bahasa Arab, yang menjadi bahasa Internasional sekarang ini.

Terdapat empat keterampilan dalam pembelajaran bahasa Arab, yaitu keterampilan mendengar, keterampilan berbicara, keterampilan membaca, dan keterampilan menulis. Bagi peserta didik, untuk memahami pesan, informasi, dan serangkaian gagasan yang terkandung dalam materi pembelajaran, arahan, dan motivasi pengajar adalah dengan menyimak. Dengan kata lain, pembelajaran menyimak ini wajib melibatkan mereka secara aktif melalui berbagai aktivitas yang mampu melatih keterampilan untuk menangkap dan memahami bahasa lisan. Tujuan utama dari pembelajaran menyimak ini adalah pembinaan peserta didik dalam penguasaan berbagai ilmu pengetahuan, seperti pengetahuan konseptual, informal, prosedural, dan juga pengetahuan metakognitif. (Izzan, 2007)

Keterampilan menyimak termasuk salah satu keterampilan reseptif dalam berbahasa, hal itu merupakan unsur yang harus dikuasai terlebih dahulu oleh peserta didik dalam pembelajaran bahasa Arab. Untuk mendapatkan kemampuan ini dengan maksimal, mereka harus berlatih secara kontinyu dalam mendengarkan perbedaan bunyi, fonem makhraj huruf, yang diucapkan oleh pengajar ataupun oleh penutur asli Arab, atau juga melalui rekaman, dan lain-lain.

Dengan demikian, pengajar didorong untuk menguasai berbagai konsep tentang pembelajaran menyimak, supaya mampu melaksanakan pembelajarannya secara benar. Tanpa adanya persiapan yang maksimal 


\section{Nur Toifah}

dalam rancangan pembelajaran, maka tidak akan mampu mencapai tujuan yang diharapkan secara maksimal. (Abidin, 2015). Dengan itu, hendaknya seluruh pengajar mempersiapkannya secara sungguh-sungguh dengan persiapan yang matang dan mendalam, salah satunya dengan penggunaan media pembelajaran yang sesuai dengan keterampilan menyimak tersebut.

\section{B. Metode}

Penelitian ini menggunakan metode kualitatif deskriptif, dilaksanakan di kelas ST.12 PKPBA UIN Maulana Malik Ibrahim Malang tahun ajaran 2020/2021. Data yang digunakan berbasis lapangan dan kajian pustaka. Data dikumpulkan melalui portofolio kelas, dokumen pembelajaran, juga melalui teks buku dan artikel, yang selanjutnya dianalisis kemudian direduksi secara deduktif yang bertujuan menghasilkan hasil penelitian deskriptif.

Pengumpulan data dilakukan dengan berbagai tahapan, yaitu: pengumpulan data portofolio kelas, dokumen kegiatan pembelajaran, serta pengumpulan beberapa literatur tentang fokus penelitian. Selanjutnya kumpulan data tersebut ditelaah dan diklasifikan antara yang paling penting dibutuhkan dan tidak penting, yang kemudian direduksi. Dan tahapan paling akhir yaitu pengambilan kesimpulan secara deskriptif. (Sugiyono, 2010).

\section{Hasil dan Pembahasan}

\section{Orientasi Pembelajaran Menyimak Arab}

Pembelajaran menyimak dilaksanakan untuk mencapai berbagai tujuan. Menururt Abidin (2015) secara esensial minimalnya ada tiga tujuan penting pembelajaran menyimak yang bersifat hierarki satu sama yang lain. Ketiga tujuan tersebut adalah: 
1. Melatih daya konsentrasi peserta didik

Orientasi pembelajaran menyimak Arab adalah supaya peserta didik mampu memusatkan perhatiannya terhadap bahan simakan yang diperdengarkan. Atas dasar tersebut, hendaknya pengajar memberikan pengetahuan, melatih, dan membiasakan mereka untuk menfokuskan perhatian total dengan berbagai strategi dan media peningkatan konsentrasi yang sesuai. Hal ini dapat dilakukan oleh pengajar dengan mempersiapkan startegi konsentrasi dengan tepat, yang mana peserta didik dituntut beraktivitas secara aktif dengan berbagai kegiatan yang dapat membiasakan dirinya berkonsentrasi. Dengan demikian, peserta didik harus melakukan aktivitas nyata yang dapat membantunya dalam memusatkan perhatian selama menyimak, seperti membuat peta konsep apa yang telah didengar, menulis ide pokok, memprediksi isi materi menyimak, dan lain-lain.

2. Melatih pemahaman peserta didik

Pembelajaran ini melatih kemampuan kognitif peserta didik disamping kemampuan auditifnya. Strategi yang dapat diimplementasikan oleh pengajar seperti beradu argument, bertukar ide, merespon suatu bacaan, dan kegiatan lain yang sejenis. Tanpa penggunaan strategi ini, pembelajaran menyimak akan menjadi semu, yang mana peserta didik hanya mampu menjawab pertanyaan saja.

3. Melatih daya kreatif peserta didik

Pembelajaran menyimak ini berorientasikan pada peningkatan kreatifitas peserta didik terhadap dasar ide bahan simakan. Pembelajaran keterampilan menyimak juga berkoheren dengan keterampilan lain, yaitu menulis dan berbicara. Dengan begitu, mereka akan berkreasi dalam tulisan, pembicaraan atas ide, dan gagasan lainnya yang mereka dengarkan. maka, muncullah istilah menyimak kritis kreatif, yang mana menuntut penyimak untuk mengkritisi isi materi simakan, juga mampu membuat produk lain atasnya. 


\section{Tahapan dalam Pembelajaran Menyimak Arab}

Menurut Mustofa (2011) bahwa tahapan pembelajaran menyimak Arab meliputi latihan pengenalan (identifikasi), latihan mendengarkan dan menirukan, latihan mendengarkan dan mamahami. Berikut ini penjelasannya:

\section{Latihan pengenalan (identifikasi)}

Tahapan latihan pertama ini sangat penting dalam pembelajaran menyimak, karena pembelajaran bahasa ke-dua tidak sama dengan bahasa ibu. Dan yang perlu untuk diajarkan pada tahapan ini adalah pengenalan bunyi bahasa.

Tahap pertama ini bertujuan untuk mengidentifikasi bunyi-bunyi Arab secara tepat dan benar. Hal ini harus diajarkan secara terus-menerus, karena sangat penting dalam pengenalan tata bunyi Arab, yang berbeda jauh dengan tata bunyi bahasa Indonesia juga daerah peserta didik. Perbedaan bunyi, kemiripan bunyi, dan bunyi yang asing bagi peserta didik menjadi perhatian khusus dalam pembelajaran pada tahapan ini.

2. Latihan mendengarkan dan menirukan

Kegiatan utama dalam pembelajaran menyimak dalah latihan mendengar, tetapi terdapat kegiatan-kegiatan pendamping juga sebagai interpetasi menyimak, yaitu latihan pengucapan dan pemahaman. Pemahaman inilah yang menjadi tujuan utama dalam pembelajaran ini. Dengan demikian, rangkaian kegiatan pembelajaran ini dimulai dari mendengar, mengenal bunyi bahasa Arab, mengucapkan, dan terakhir adalah memahaminya.

\section{Latihan mendengarkan dan memahami}

Setelah beberapa bunyi bahasa sudah dikenal oleh peserta didik,kemudian diucapkan oleh mereka, kegiatan atau latihan selanjutnya adalah memahami apa yang sudah didengar. Beberapa latihan mendengar ini bisa dilakukan dengan teknik yang bervariatif, meliputi: 
a) Latihan melihat dan mendengar

Latihan ini dapat dilakukan oleh pengajar dengan memberikan rekaman materi pembelajaran. Dalam waktu yang bersamaan, ia menunjukkan gambar yang menghubungkan isi juga arti dari materi yang didengarkan oleh mereka. bentuk dari gambar tersebut berupa slide, strip, film, dan lain-lain.

b) Latihan membaca dan mendengar

Dalam latihan ini, pengajar memberikan rekaman materi pembelajaran kepada peserta didik, selanjutnya mereka mengikuti untuk membaca sendiri dalam hatinya. Jika peserta didik berada pada tingkat dasar (pemula), yang mana perbendahaarn kosakatanya masih minim, maka materi simakan diambil dari percakapan sehari-hari atau ungkapan sederhana yang familiar di telinga mereka, dalam artian kata atau kalimat yang dijadikan materi pembelajaran bentuknya pendek-pendek.

c) Latihan mendengarkan dan memperagakan

Latihan ini dapat dilakukan dengan meminta peserta didik untuk bergerak atau bergaya sesuai dengan kata atau kalimat yang didengar, hal ini sebagai jawaban dari apa yang diucapkan oleh pengajar. Latihan dalam bentuk ini tidak sebatas pada kalimat sehari-hari saja, tetapi boleh diambil dari cerita atau juga bacaan. Latihan ini menuntut peserta didik untuk fokus dalam mendengar dan mengingat kalimat yang diucapkan, karena dengan itu, mereka dapat menyimpulkan dengan baik dan benar.

\section{Prinsip-Prinsip Pembelajaran Menyimak Arab}

Mustofa (2011) berpendapat bahwa terdapat beberapa prinsip yang perlu diperhatikan oleh seorang pengajar dalam pembelajaran menyimak, yaitu: 
1. Kalimat yang diperdengarkan harus jelas

Seorang pengajar harus membuat kalimat yang diperdengarkan kepada peserta didik dengan jelas antara kalimat pernyataan dengan kalimat pertanyaan. Rangkaian bunyi bahasa dengan susunan nada dan tekanannya memudahkan peserta didik dalam menerima informasi. Seringkali dijumpai bahwa susunan kalimat tanya sama dengan kalimat berita, hal ini yang menyebabkan peserta didik menjadi bingung.

2. Memahami topik bahasan

Topik suatu materi pembelajaran harus difahami dahulu oleh peserta didik sebelum mulai belajar. Hendaknya mereka diajarkan dan dilatih dalam membedakan gagasan pokok dan gagasan penunjang/sampingan.

3. Pemilihan topik bahasan

Seorang pengajar harus cerdas dalam menentukan dan topik bahasan, juga pandai dalam memperhatikan hal-hal berikut ini:

a. Umur dan minat peserta didik,

b. Kosakata yang dimilikinya,

c. Tingkat ketepatan dan kecepatan mereka dalam mendengarkan teks

lisan. Topik yang disampaikan berurutan dari yang mudah ke sulit, pendek ke panjang, dari konkrit ke abstrak.

4. Penyajian teks

Dalam pembelajaran menyimak arab, hendaknya ucapan pengajar diperlambat jedanya, terutama pada peserta didik tingkat dasar/pemula. Dalam penyajiannya, dilakukan secara berulang dua sampai tiga kali, atau sesuai kebutuhan peserta didik.

5. Pemberian kata kunci

Kata kunci boleh diberikan dan dijelaskan maknanya dalam pembelajaran menyimak Arab, serta disampaikan sebelumnya. Namun tidak semua kata baru dielaskan maknanya, hal ini untuk memberikan kesempatan menerka kepada mereka. 


\section{Memberikan petunjuk yang jelas}

Petunjuk atau instruksi seorang pengajar kepada peserta didik hendaknya disampaikan dengan jelas. Hal ini bertujuan untuk merangsang mereka dalam memahami materi, juga menjadikan mereka semangat dalam memahami teks yang dipelajari.

7. Memberi pertanyaan-pertanyaan

Pemahaman peserta didik dapat diketahui dari jawaban-jawaban mereka terhadap beberapa pertanyaan yang diajukan oleh pengajar kepada mereka. dengan demikian, hendaknya setiap materi pembelajaran yang disajikan dilengkapi dengan pertanyaan-pertanyaan yang tepat dan benar.

\section{Media Pembelajaran}

Dalam pembelajaran, penggunaan alat peraga atau media sangat bermanfaat dan dapat membantu mempercepat pengertian dan pemahaman peserta didik. Tetapi ada kalanya alat peraga ini dengan sengaja tidak dipakai supaya peserta didik tidak terlalu banyak menggantungkan diri pada isyarat yang diperolehnya dari alat tersebut. Ada saatnya mereka harus dilatih dalam memahami teks-teks materi keterampilan menyimak dari isyarat yang diterimanya melalui gerbang telinga.

Media berasal dari kata "Medius" diambil dari bahasa latin, yang berarti "tengah". Media merupakan perantara untuk membawa, menyebar, dan menyampaikan suatu pesan kepada si penerima. Sedangkan media pembelajaran adalah seseorang, alat, bahan, atau peristiwa yang membantu peserta didik dalam menerima dan mendapatkan sikap, pengetahuan, juga keterampilan. (Ashar, 2012)

Arsyad (2004) berpendapat bahwa segala sesuatu yang didapatkan melalui informasi dan pesan dalam interaksi pembelajaran disebut dengan media. Berdasarkan sejarah, istilah media pembelajaran adalah visual education (alat peraga pandang), kemudian istilah tersebut berubah menjadi 
audio-visual aids (bahan pengajaran), selanjutnya berkembang menjadi audio-visual communication (komunikasi pandang dengar), yang terakhir disebut dengan educational tecnology (teknologi pendidikaan) atau juga teknologi pembelajaran.

\section{Manfaat Media Pembelajaran}

Terdapat beberapa manfaat dalam media pembelajaran, seperti dapat menjelaskan materi dengan lebih konkrit, logis dan jelas, contohnya pembelajaran menyimak dengan media film, video, gambar, foto, miniatur, komputer, dan lain-lain. Media pembelajaran juga meningkatkan motivasi belajar, aktivitas pembelajaran ataupun pemahaman peserta didik terhadap materi. Sebagaimana yang dijelaskan oleh Arsyad (2009) bahwa media pembelajaran bermanfaat dalam penjelasan juga penyajian pesan dan informasi, dengan demikian proses dan hasil belajar dalat diperlancar dan ditingkatkan dengannya.

Menurut Sudjana \& Rivai (2002) bahwa terdapat beberapa manfaat media pembelajaran dalam proses pembelajaran, yaitu:

1. Peserta didik akan tertarik dengan media pembelajaran, sehingga motivasi belajar mereka dapat ditumbuhkan dengannya.

2. Memperjelas bahan atau materi pembelajaran, sehingga peserta dapat menerima juga memahaminya dengan cepat dan mudah. Dengan demikian, tujuan pembelajaran akan tercapai dengan baik.

3. Menjadikan metode dan strategi pembelajaran bervariatif. Hal ini menjadikan pengajar lebih ringan dalam pembelajarannya, tetapi membutuhkan persiapan yang lebih matang.

4. Menumbuhkan aktivitas dan kreasi peserta didik, karena mereka tidak hanya mendengarkan penjelasan pengajar, tetapi beraktivitas lain seperti mengamati, menjelaskan, melakukan, mendemostrasikan, memerankan, dan lain-lain. 


\section{Landasan Penggunaan Media Pembelajaran}

Terdapat beberapa factor yang menjadi landasan dalam penggunaan media pembelajaran, Daryanto (2010) mengungkapkan bahwa tinjauan tentang landasan penggunaan media pembelajaran meliputi:

1. Landasan psikologis

Kajian ini menjelaskan bahwa hal-hal yang konkrit lebih mudah dipelajari oleh anak dari pada hal-hal yang abstrak.

\section{Landasan teknologis}

Teknologi pembelajaran merupakan teori dan praktek perancangan, pengembangan, penerapan, pengelolahan dan penilaian proses serta menjadi sumber belajar.

\section{Landasan empiris}

Hasil dari temuan peneliti menjelaskan bahwa hasil belajar peserta didik sangat ditentukan dengan adanya interaksi pemanfaatan media pembelajaran yang sesuai dengan kebutuhan dan tata cara penggunaannya yang tepat.

Dengan demikian, hendaknya setiap pengajar memahami dasar-dasar dan kriteria dalam pemilihan media pembelajarannya, seperti kesesuaian media dengan tujuan pembelajaran yang akan disampaikan, sesuai dengan kemampuannya dalam pengoperasian, sesuai dengan situasi dan kondisi, mengerti dari karakteristik media pembelajaran, dan cerdas dalam menentukan media yang sesuai dengan fase perkembangan peserta didik. (Sadiman, 2002).

\section{Software "Camtasia Studio"}

Camtasiastudioadalah perangkatlunak(software)yang dikembangkan oleh TechSmith Coorporation khusus bidang multimedia. Ia merupakan program aplikasi yang didesain untuk recording, editing, dan publishing dalam pembuatan video presentasi pada layar (screen) komputer. Software 


\section{Nur Toifah}

ini digunakan untuk mengcapture tampilan layar monitor, dengan tambahan audio dan video, bisa juga dimanfaatkan untuk merekam hasil presentasi powerpoint ke dalam format video. Dengannya, pengguna sangat terbantu dan terlatih dalam penyampaian sesuatu juga dapat berinteraksi dengan audiens. Kemampuannya dalam merekam suara yang ada dalam layar tidak diragukan lagi, termasuk dalam kegiatan di desktop, presentasi powerpoint, narasi suara, dan webcam video. Dengannya, satu mata pelajaran yang penuh video gerak atau presentasi dapat direkam dan diciptakan oleh penggunanya dengan hasil yang maksimal. (Putra dkk, 2017)

\section{Kelebihan Camtasia Studio}

Setiap software mempunya kelebihan dan kekurangan, termasuk juga software Camtasia Studio. Diantara kelebihan dari software ini adalah:

1. Kualitas hasil video yang baik.

2. Mudah dioperasikan dan sangat sederhana, sehingga memudahkan setiap penggunanya dalam membuat video dalam waktu yang cukup singkat.

3. Halaman web, software aplikasi, dan lainnya dapat direkam pada layar komputer. Perbedaan konten/isi dalam presentasi Powerpoint mudah dipadukan juga menghemat peralatan.

4. Software Camtasia Studio ini tidak membutuhkan server, karena ia bukan program aplikasi berbasis server. Ia dapat didiinstall pada harddisk komputer, dan tidak butuh hubungan dengan server ketika ingin membuat rekaman video.

5. Tersedia fasilitas editing yang lengkap. Camtasia Studio ini memiliki fasilitas editing yang sempurna dalam peningkatan kebutuhan multimedia pada video, yaitu: (a) Edit audio dan track video, (b) Membuat interaktif Flash dan Callouts, (c) Tulisan teks ditambahkan dengan add pada video, (d) Video dimaukkan dalam presentasi 
melalui Screen video.

6. Tanpa ada batasan Format file. Software ini mampu menyimpan hasil rekaman dalam berbagai jenis format file, seperti Macromedia Flash (*.swf,*.flv), Apple Quick Time (*.mov), Windows Media (*.wmv), dan *avi.

7. Compatible dengan tools lainnya. Compatible dengan tools CMS (Course Management System) atau LMS (Learning Management System), seperti webCT, Blackboard, eXe, dan Moodle (Dariyadi, 2016:212).

\section{Cara Penggunaan Software Camtasia Studio}

1. Pada saat membuka Camtasia Studio, akan tampak pertama kali sebagaimana pada gambar 1 di bawah ini.

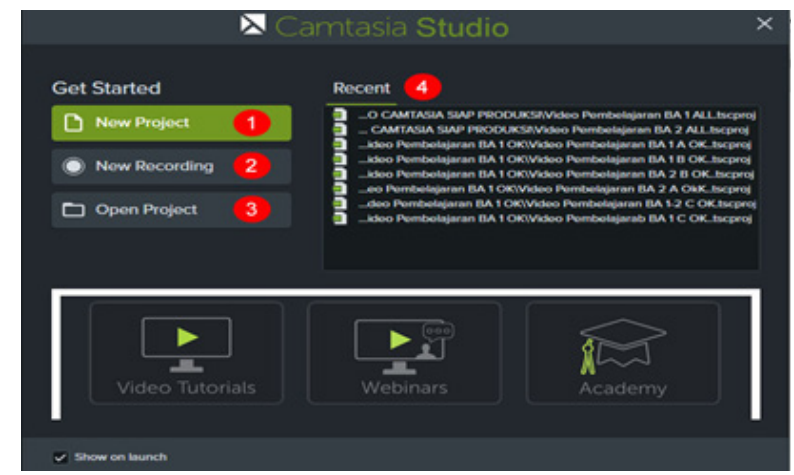

Gambar 1: Halaman depan software camtasia studio

a. Pada gambar nomer 1 adalah New Project di mana gambar tersebut mengarahkan pada halaman baru apabila programer menghendaki halaman baru dalam pembuatan video.

b. Pada gambar nomer 2 menerangkan tentang rekaman baru apabila programer menginginkan rekaman baru.

c. Pada gambar nomer 3 menerangkan tentang tata cara membuka file 


\section{Nur Toifah}

secara langsung yang sudah pernah disimpan pada screen Camtasia Studio.

d. Recent adalah penampilan file-file yang sudah pernah digunakan saat mengedit. Dan apabila programer ingin membuka file secara langsung, maka tinggal mengarahkan cursornya ke file recent yang sudah tercantum.

2. Area kerja Camtasia Studio

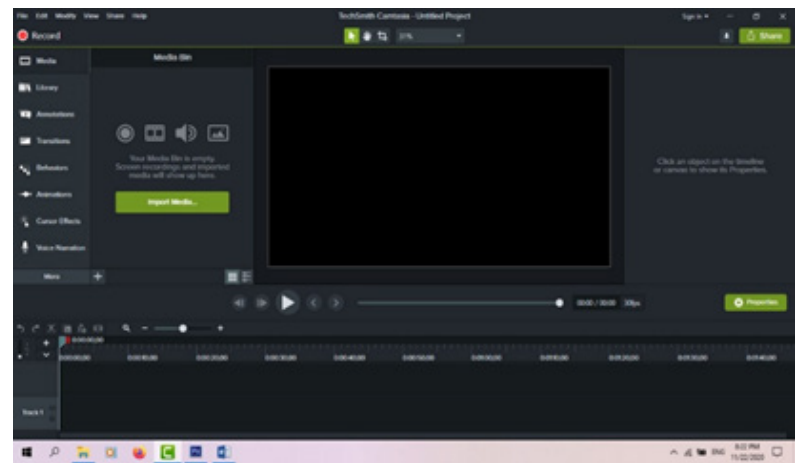

Gambar 2: Fitur software camtasia studio

a. Record: Untuk langsung membuka Camtasia Recorder dan merekam aktivitas Desktop computer.

b. Library: untuk membuka Icon-icon unik di Sofware Camtasia Studio.

c. Annotations: Untuk menulis teks di screen video maupun kolom komentar yanghendak dibuat video pembelajaran.

d. Transitions: untuk membuat animasi potongan dalam video.

e. Behavior: Untuk membuat animasi gambar-gambar bergerak dalam pembuatan video pembelajaran.

f. Animation: Untuk membuat animasi-animasi tulisan dan gambar bergerak dalam video pembelajaran. 
g. Import Media: Memilih video, Audio, maupun gambar untuk dimasukkan ke dalam area kerja. (Supriyanto dan Erawanto, 2020)

\section{Pembelajaran Menyimak Arab dengan Video Camtasia Studio}

Terdapat tiga tahapan dalam pembelajaran menyimak Arab dengan video Camtasia studio, yaitu tahap pendahuluan, tahap inti pembelajaran, dan tahap penutup. Berikut ini langkah-langkah kegiatan pembelajarannya: 1. Tahap Pendahuluan, yang mencakup beberapa kegiatan yang dilakukan oleh pengajar, yaitu:

a. Orientasi

- Membuka pembelajaran dengan salam, juga do'a sebelum belajar, atau pembacaan salah satu surat dari juz 30

- Membacakan absensi kehadiran peserta didik

- Menkondisikan fisik dan psikis peserta didik dalam permulaan pembelajaran

b. Apersepsi

- Mengaitkan atau menghubungkan materi pembelajaran yang sudah dipelajari di pertemuan sebelumnya dengan materi yang akan dipelajari

- Memberikan beberapa pertanyaan kepada peserta didik, hal ini bertujuan untuk mengingat kembali memori mereka terhadap materi yang sudah dipelajari.

c. Motivasi

- Memberikan gambaran secara umum tentang materi yang akan dipelajari

- Memotivasi peserta didik untuk belajar dengan semangat dan sungguh-sungguh, dan memberitahu kepada mereka bahwa akan belajar dengan media video yang menarik dan menyenangkan. 


\section{d. Pemberian Acuan}

- Menyampaikan materi yang akan dipelajari

- Menjelaskan tujuan pembelajarannya

- Menjelaskan prosedur proses pembelajarannya

2. Tahap inti pembelajaran (kegiatan inti)

a. Mengamati

- Memberikan stimulus mufrodat/kosakata yang baru yang berhubungan dengan tema "cita-cita" الهوايـة

- Meminta kepada peserta didik untuk membaca mandiri kosa kata tersebut

- Meminta kepada peserta didik untuk menanyakan kosa kata yang belum difahami

- Memberikan kesempatan kepada peserta didik untuk memberi tanggapan tentang makna kosa kata dari teman yang belum faham, jika semuanya belum faham, maka pengajar menjelaskan maknanya yang benar.

b. Mengeksplorasi

- Meminta kepada peserta didik untuk memperhatikan dengan seksama video pembelajaran yang akan dipelajari.

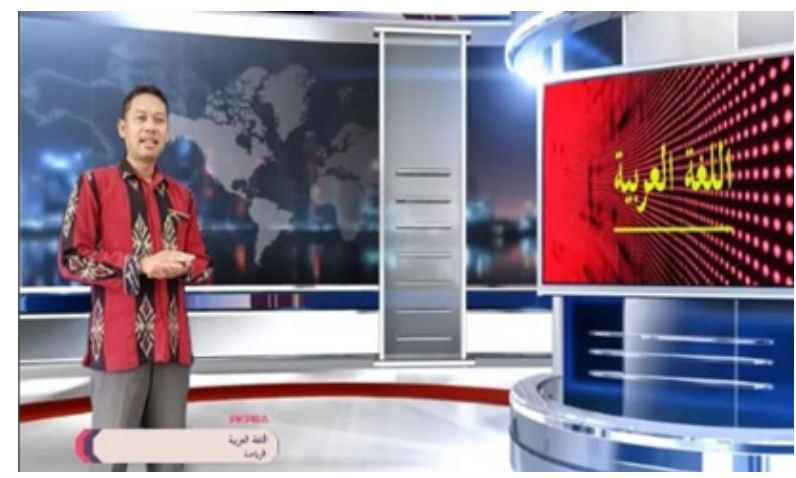

Gambar 3: Video pendahuluan pembelajaran menyimak Arab 
Camtasia Studio: Software multimedia dalam Pembelajaran ...

- Memutar video pembelajaran menyimak Arab dengan tema “cita-cita" المزنــة melalui aplikasi zoom.

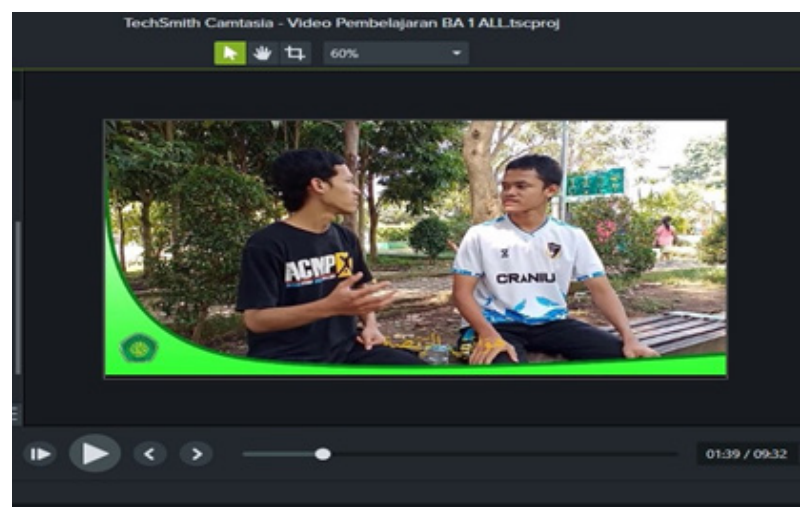

Gambar 4: Video percakapan tentang "hobi / الهو اية dengan software Camtasia studio

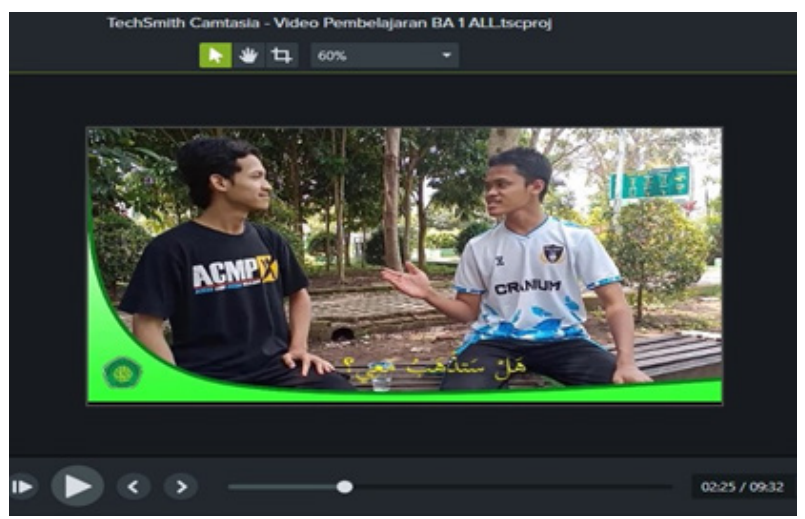

Gambar 5: Video percakapan tentang "hobi / الهو اية "dengan software Camtasia studio

- Mendiskusikan makna percakapan dalam video pembelajaran secara kalimat per kalimat bersama peserta didik. 
Nur Toifah

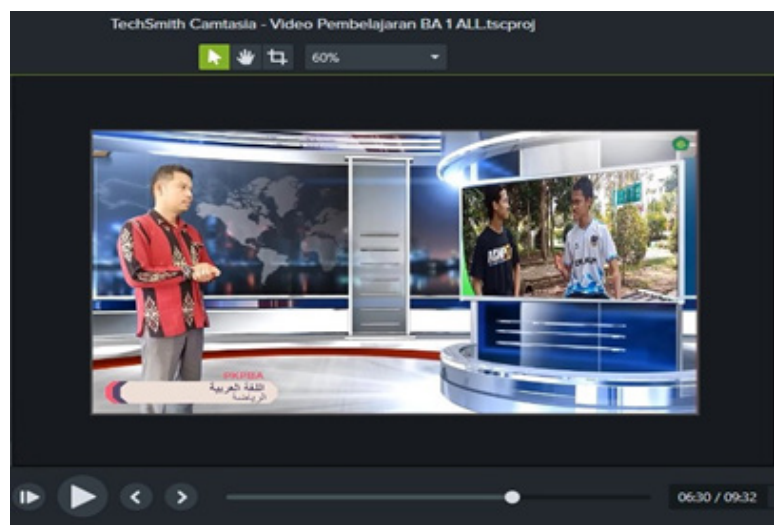

Gambar 6: Video pembahasan makna percakapan tentang "hobi / الهو "kalimat per kalimat dengan software Camtasia studio

c. Mengasosiasi

- Setelah selesai pemutaran video dan diskusi tentang penjelasan maknanya, pengajar menanyakan pemahaman peserta didik tentang video, dan memberikan kesempatan kepada mereka untuk memahaminya sendiri dengan menyaksikan video pembelajaran sekali lagi bersama-sama.

d. Mengkomunikasi

- Memberikan beberapa pertanyaan yang berhubungan dengan isi video pembelajaran secara umum kepada semua peserta didik

- Meminta kepada sebagian peserta didik untuk menceritakan kembali video pembelajaran dengan menggunakan bahasa Arab mereka.

- Meminta kepada peserta didik lain untuk menanggapi cerita temannya

- Memberikan umpan balik dan penguatan nilai terhadap masingmasing peserta didik yang sudah bercerita. 
3. Tahap penutup

a. Pengambilan kesimpulan

- Peserta didik menyimpulkan poin-poin penting dalam video pembelajaran dengan bimbingan pengajar

b. Refleksi dan evaluasi

- Merefleksi atau mengevaluasi pembelajaran bersama peserta didik, baik dalam hal kelebihan dan kekurangan dari belajar dengan video pembelajaran, maupun dalam hal kesulitan yang dihadapi mereka

- Memberikan tugas (PR) kepada peserta didik untuk melakukan hiwar/percakapan dengan teman tentang materi yang sudah dipelajari (hobi/الهوايـة) melalui video call dan merekamnya.

c. Motivasi

- Memberikan motivasi kepada peserta didik untuk belajar dengan sungguh-sungguh terutama dalam pembelajaran menyimak Arab, juga menyampaikan manfaatnya dalam pembelajaran juga dalam kehidupan

d. Penutup

- Menutup pembelajaran dengan do’a dan salam

\section{Simpulan}

Salah satu media yang dapat diaplikasikan dalam pembelajaran menyimak Arab adalah video Camtasia studio, yang mana media tersebut dapat dibuat dengan mudah oleh pengajar sesuai dengan tema, karena pengoperasiannya sangat mudah. Ia dapat diaplikasikan dalam pembelajaran tanpa batasan waktu, baik dalam pembelajaran luring (luar jaringan) ataupun daring (dalam jaringan). Terdapat tiga tahapan dalam pembelajaran menyimak Arab dengan media Camtasia studio, yaitu pertama: tahap pendahuluan, yang mencakup orientasi, apersepsi, motivasi, 
pemberian Acuan, ke-dua: tahap inti pembelajaran (kegiatan inti), yang mencakup mengamati, mengeksplorasi, mengasosiasi, mengkomunikasi, dan ketiga: tahap penutup, yang mencakup pengambilan kesimpulan, refleksi dan evaluasi, motivasi, serta penutup.

Media ini mempunyai beberapa manfaat, seperti: meningkatkan motivasi belajar pesera didik, merubah tingkah laku, memberikan motivasi baru dan penyegaran, memberikan pelajaran yang bermakna, memperluas pengalaman dan wawasan, serta tercapainya tujuan pembelajaran menyimak Arab, juga terbentuknya generasi Bangsa yang siap menghadapi era digital atau era revolusi industry 4.0.

\section{Daftar Pustaka}

Abidin, Yunus. 2015. Pembelajaran Bahasa Berbasis Pendidikan Karakter. Bandung: PT. Refika Aditama.

Achsin. 1986. Media Belajar. Jakarta: Rineka Cipta.

Aripin. 2009. Step by Step Membuat Video Tutorial Menggunakan Camtasia

Studio. Bandung: Oase Media

Arsyad, Azhar. 2004. Bahasa Arab dan Metode Pengajarannya. Yogyakarta: PustakaPelajar.

Suryatri Darmin, Daryanto dan Bintoro. 2013. Implementasi Pendidikan Karakter di Sekolah. Yogyakarta: Gava Media . 2007. Media Pembelajaran. Jakarta: PT. Raja Grafindo Persada.

Suyadi. 2015. Strategi Pembelajaran Pendidikan Karakter. Bandung: PT. Remaja Rosdakarya Offset.

Ashar, Rayandra, 2012, Kreatif Mengembangkan Media Pembelajaran, Jakarta : Referensi Jakarta

Dariyadi, Moch Wahib, 2016, Penggunaan Software "Camtasia Studio" 
Sebagai Media Pembelajaran Bahasa Arab Berbasis ICT. Malang: Prosiding Konferensi Nasional Bahasa Arab II.

Daryanto. 2010. Media Pembelajaran, Yogyakarta: Gava Media

Izzan, Ahmad. 2007. Metodologi Pembelajaran Bahasa Arab. Bandung: Humaniora Penerbit Buku Pendidikan.

Mustofa, bisri dan Abdul Hamid, Mohammad. 2016. Metode dan Strategi Pembelajaran Bahasa Arab. Malang: UIN-MALIKI PRESS.

Mustofa, Syaiful. 2011. Strategi Pembelajaran Bahasa Arab Inovatif. Malang: UIN MALIKI PRESS.

Putra, Iskandar, K. UdyAriawan, I.W. Sutaya. 2017. Pengembangan Media Pembelajaran Berbasis Camtasia Studio Video CD Interaktif Multimedia Untuk Mata Pelajaran Pemrograman Web Di Jurusan Multimedia SMK Negeri 3 Singaraja. Jurnal Pendidikan Teknik Elektro Undiksha Vol. 6 No. 1.

Rukiyah, Siti, 2020, Pembelajaran Bahasa Indonesia Di Era Revolusi Industri 4.0, Prosiding Seminar Nasional Pendidikan Program Pascasarjana Universitas Pgri Di Palembang.

Sudjana, Nana dan A. Rivai. 2002. Media Pengajaran. Bandung: Alfabeta Sugiyono, 2010. "Model Penelitian Kuantitatif Kualitatif". Bandung: Alfabeta.

Supriyanto, Very Erawanto, 2020, Pengembangan Media Pembelajaran "Camtasia Studio" untuk Maharotul Kalam di PKPBA Uin Maulana Malik Ibrahim Malang Selama Pandemi Covid-19. Malang: Laporan Penelitian Kompetitif PMU dan LP2M UIN Malang. 